\title{
UFRS 3 İşletme Birleşmeleri Standardı Kapsamında Ters İşletme Birleşmeleri ve Muhasebeleştirilmesi
}

\author{
Olcay Akçin ${ }^{\mathrm{a}}$
}

\author{
İlker Kıymetli Şen ${ }^{b}$
}

\begin{abstract}
Öz: Küresel ekonominin etkileri neticesinde oluşan zorlu rekabet koşulları ile birlikte teknolojik gelişmeler, tüketici tercihlerinde yaşanan değişimler, ekonomik krizler, yasalardaki değişimler ve sayılabilecek bir çok başka nedenden ötürü şirketler büyüme, karşılaştkları riskleri düşürme, etkinlik, verimlilik ve rekabet güçlerini artirma, yeni pazarlara açılma ve maliyetlerini azaltma amacıyla birleşmeler gerçekleştirmektedir. Uluslararası Finansal Raporlama Standartları uyarınca raporlama yapan işletmeler gerçekleştirdikleri işletme birleşmelerinin muhasebeleştirilmesinde UFRS 3 işletme Birleşmeleri standardı hükümlerini uygulamaktadır. Literatürde "Ters İşletme Birleşmeleri" şeklinde nitelendirilen işlemler söz konusu standart içerisinde ayrı bir başlık altında ele alınmıştır. Standart uyarınca klasik işletme birleşmeleri ile ters işletme birleşmelerine ilişkin muhasebeleştirme işlemleri birçok yönden farklılık göstermektedir. Bu çalışmanın amacı ters işletme birleşmelerine ilişkin muhasebeleştirme işlemlerinin klasik işletme birleşmelerinden ayrılan noktalarının teorik ve pratik olarak açıklanmasıdır.
\end{abstract}

Anahtar Sözcükler: UFRS, İşletme Birleşmeleri, Ters Birleşme, Gerçeğe Uygun Değer, Konsolidasyon

JEL Sınıflandırması: M40, M41, M42

\section{Reverse Acquisitions Within the Scope of IFRS 3 Business Combinations}

\begin{abstract}
Because of tough competition conditions in global economy, technological developments, changes in consumer preferences, economic crisis, changes in law and number of other reasons, companies choose business combinations in order to reduce the business risks, increase the performance, efficiency and competitive power, expand into new markets and reduce the costs. Companies reporting in accordance with International Financial Reporting Standards apply IFRS 3 Business Combinations while accounting of business combinations. Transactions defined as "Reverse Acquisitions" in the literature are discussed in a separate chapter within the standard. As per the standard, accounting treatments for reverse acquisitions differ in many ways from regular business combinations. The purpose of this study is to explain the theoretical and practical accounting treatment differences between regular business combinations and reverse acquisitions.
\end{abstract}

Keywords: IFRS, Business Combinations, Reverse Acquisition, Fair Value, Consolidation

JEL Classification: M40, M41, M42

aPhD. Candidate, Certified Public Accountant, Istanbul Commerce University, Institute of Social Sciences, Department of Accounting and Auditing, Istanbul, Turkiye, olcay.akcin@gmail.com (ORCID ID: 0000-0001-9075-8285)

${ }^{b}$ Assoc. Prof., PhD., Certified Public Accountant, Istanbul Commerce University, Faculty of Business, Department of Accounting and Auditing, Istanbul, Turkiye, ilksen@ticaret.edu.tr (ORCID ID: 0000-0001-6175-3397) 


\section{Giriş}

İşletmeler yapılarına, kuruluş nedenlerine, içinde bulundukları ekonomik düzenin koşullarına, yönetim anlayışlarına ve buna benzer diğer etkenlere bağlı olarak farklı amaçlar güdebilmektedir. Günümüzde işletmelerin amacı,

- Varlıklarını sürdürmek, var oluşlarına yönelebilecek tehlikeleri, başka bir deyişle riskleri en düşük düzeye indirmek,

- Büyüme hızlarını artırarak en yüksek düzeye çıkarmak,

- Bağımsızlıklarını koruyabilmek ve büyümenin gerektirdiği finansman gereksiniminin en azından bir bölümünü karşıllayabilmek için yeterli iç kaynakları yaratmaktır (Akgüç, 1998: 889).

Genel olarak ifade edilirse işletmelerin en önemli amaçlarından biri pazar değerlerini artırmaktır. İşletme birleşmeleri şirketlerin pazar değerlerinin artırılması için kullanılan önemli bir yöntem olarak literatürde yer almaktadır (Akgüç, 1998: 889).

Işlem olarak işletme birleşmelerinin yaygınlaşması ile muhasebe ve finansal raporlama alanında bu işlemlerin sunumlarına ilişkin problemler ortaya çıkmaya başlamıştır. Gerek lokal regülasyonlar ve gerekse de uluslararası standartlar kapsamında zaman içerisinde bu işlemlerin finansal tablo kullanıcılarının daha doğru karar alabilmelerine yönelik geliştirme çalışmaları yürütülmüştür. UFRS 3 içerisinde özellikli bir durum olarak ayrı bir başlık altında ele alınmış olan ters işletme birleşmelerine ilişkin muhasebeleştirme hükümleri de bu çalışmaların bir sonucudur. Edinen ve edinilen işletmenin belirlenmesi ve transfer edilen bedelin gerçeğe uygun değerinin ölçümü başta olmak üzere muhasebeleştirme işlemlerindeki önemli farklılıkların bulunması, ters işletme birleşmelerinin uygulamada klasik işletme birleşmelerinden farklı bir muhasebe perspektifinden değerlendirilmesi gerektiğini ortaya koymaktadır. Bu çalışmada söz konusu farklııklar teorik ve pratik olarak açıklanmaktadır.

\section{2. İşletme Birleşmeleri}

Ticaret ortaklıklarının, özellikle sermaye ortaklıklarının birleşmesiyle ilgili olarak çeşitli ülkelerin yasal düzenlemelerinde farklı kavramlar kullanılmaktadır. Avrupa dillerinin pek çoğunda işletme birleşmeleri küçük söyleniş ve yazılış farklılıklarıyla Latince kökenli ortak bir sözcük olan Almanca Fusion, Fransızcada Fusion ve İtalyancada Fusiona kelimeleriyle ifade edilmektedir. Anglo-Sakson hukuk çevrelerinde işletme birleşmelerini ifade etmede Merger sözcüğü ortak terim niteliğindedir. İngiliz hukukunda Amalgamation, Amerikan hukukunda Consolidation sözcükleri birleşme anlamında kullanılmaktadır (Türk, 1986: 3-4).

Literatür incelendiğinde işletme birleşmelerinin kimi kaynaklar ve Türk Ticaret Kanunu'nda "Birleşme" şeklinde tek terimle ifade edildiği, bazı kaynaklarda ise bu işlemlerin "Birleşme (Merger)", "Satın Alma (Acquisiton)" ve Devralma (Takeover)" olarak ayrı terimlerle ile ifade edildiği görülmektedir. Birleşme (Merger), şirketlerin birbirleriyle birleşerek ya tüzel kişiliğe sahip başka bir şirket kurmaları ya da bir veya bir kaçının diğer kuruma katılmaları şeklinde ifade edilmektedir (Ataman, 2000: 309). Satın alma (Acquisition), bir şirketin varlıklarının veya hisselerinin başka bir şirket tarafindan satın alınması işlemi olarak tanımlanmaktadır (Grinblatt ve Titman, 2002: 691). Devralma (Takeover) ise bir şirketin sermayesinin tamamının nakit ve/veya hisse senedi karşılığında başka bir şirket tarafindan satın alınması işlemi olarak nitelendirilmektedir (Pike ve Neale, 1996: 593). UFRS 3 işletme Birleşmeleri Standardı ise işletme birleşmelerini "Birleşme (Combination)" terimi ile ifade etmektedir (UFRS 3, m.3). Belirtilmesi gereken başka bir husus ise literatürde yukarıdaki kavramların net çizgilerle birbirinden ayrılmayıp birbirleri yerine kullanılabiliyor olmasıdır.

\section{1. İşletme Birleşmelerinin Nedenleri}

Şirketlerin işletme birleşmeleri gerçekleştirmesi ile ilgili olarak literatürde pek çok neden sayılmaktadır. Bu nedenlerin sayısı ve önem dereceleri de ülkelerin sosyo-ekonomik koşullarına, işletmelerin özelliklerine, içinde yer alınılan toplumun özelliklerine ve zamana göre çeşitlilik göstermektedir (Aydın, 1990: 23). Şekil 1'de bu nedenlerden bazıları gösterilmektedir. 
Şekil 1. İ̧letme Birleşmelerinin Nedenleri

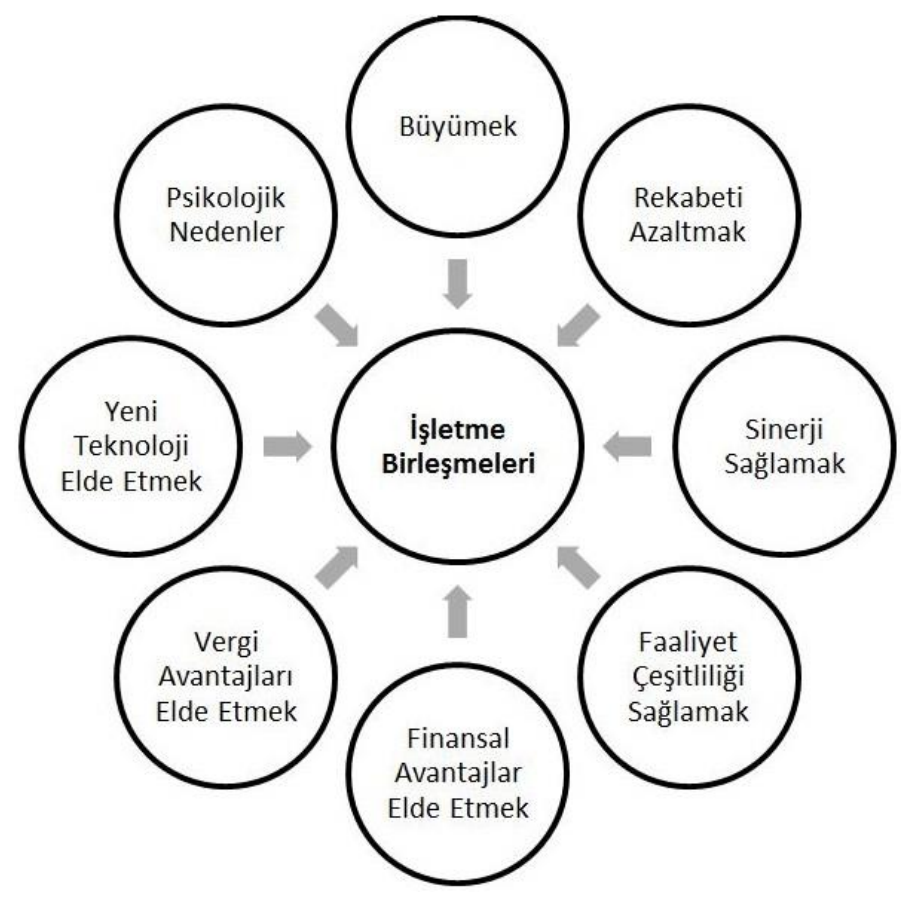

Büyümek: İşletme yazınında büyüme, işletmede sayısal (üretim miktarı, satş̧ gelirleri, ürün çeşitliliği, varlık/kaynak büyüklüğü, vb.) ve nitelik (işletme unsurlarının kalitesi) olarak bir gelişimi ifade etmektedir (Ülgen ve Mirze, 2004: 188-189). Büyümeyi hedefleyen işletmeler, içsel ve dışsal büyüme seçenekleri ile karşı karşıya kalmaktadır. İşletmelerin kendi olanaklarıyla faaliyetlerinin sonucu yarattkları kaynakları ya da sağladıkları yabancı kaynakları yeni yatırımlara ayırarak büyümeleri iç büyüme olarak tanımlanmaktadır (Griffin vd., 1980: 4). Bir işletmenin diğer işletme veya işletmelerin tamamını veya bir bölümünü ya da varlıklarını satın alarak büyümesi dış büyüme olarak nitelendirilmektedir (Akgüç, 1998: 891). Şirketler iç büyümedense diğer şirketleri elde ederek veya birleşerek yeni pazar ve bölgelere daha kolay ulaşabilmektedir (Baker vd., 2011: 7).

Rekabeti Azaltmak: İşletmelerde birleşme işlemi rakip bir firmayı bünyeye katmak maksadı ile yapıldığında, yeni şirketin pazar payı artmaktadır. Bu durum firmanın rekabet gücünü artırıcı etki göstermektedir (Sarıkamış, 2003: 20).

Sinerji Sağlamak: Sinerji, iktisat ya da finans bilimlerinden daha ziyade fizik bilimi ile ilgili bir terimdir. Sinerji, birleşen işletmelerin mevcut değerlerinin ayrı ayrı toplamlarının birleşme sonrası oluşacak toplam değerden daha düşük olması, diğer bir ifadeyle bütünün, o bütünü oluşturan parçaların toplamından daha büyük olması şeklinde tanımlanmaktadır (Brusco vd., 2004: 2).

Faaliyet Çeşitliliği Sağlamak: Durgun veya düşük büyüme hızına sahip bir işkolundaki bir işletme daha hızlı büyüyen ve büyüme potansiyeli olan daha karlı sektörlere yatırım yaparak faaliyet alanlarını çeşitlendirmek isteyebilmektedir. Yöneticiler çeşitlendirme sonucunda işletme karlarının daha istikrarlı olacağını ve işletme riskinin azalacağını beklemektedir (Weston ve Brigham, 1993: 833).

Finansal Avantajlar Elde Etmek: İ̧̧letmeler büyümek için gerekli olan finansal kaynakları bulabilmek adına likiditesi yüksek işletmelerle birleşme yoluna giderek büyümeyi sağlayacak finansman ihtiyacını karşılayabilmektedir (Yıldııım ve Kolotoğlu, 2003: 205). Bunun yanı sıra borç verenler açısından risk derecesi düşmüş olacağından, işletmeler birleşerek piyasadan ayrı ayrı borçlanabilecekleri faiz oranından daha düşük oranlarla borç bulabilme imkanına sahip olabilmektedir (Çelen, 2010: 14-15). 
Vergi Avantajları Elde Etmek: İşletmeleri birleşme stratejilerine yönlendiren en önemli nedenlerden biri de vergi yasalarının sağladığı avantajlardan yararlanarak vergi yükünü hafifletmektir (Tükenmez vd., 1999: 1086). Örneğin çok karlı ve yüksek vergi diliminde bulunan bir banka ile birikmiş büyük vergi borçları olan bir banka birleşebilir ve vergi borçlarını, gelirlerini vergiye karşı koruyan bir kalkan olarak kullanabilmektedir (Brigham, 2006: 139).

Yeni Teknoloji Elde Etmek: İşletmeler önemli teknolojik gelişmelere uyum sağlayamama durumunda bu gelişmelerin yıkıcı etkisiyle karşılaşabilmektedir. Teknolojik olarak kendilerini geliştirmek ve yukarıda bahsedilen negatif etkiden korunmak isteyen işletmeler için iki seçenek mevcut bulunmaktadır. Birinci seçenek, işletme içerisinde gelişen teknolojiyi yakalamaktır. Bu durum, araşttrma ve geliştirme maliyetlerinin yüksek olması, uzun zaman alması işletmenin stratejik ve önemli firsatları kaçırması açısından büyük risk taşımaktadır. Íkinci seçenek, işletmenin istenilen teknolojiye sahip bir işletmeyi ele geçirmesi şeklinde olup, bu durum birleşme ve satın almalar ile gerçekleştirilebilmektedir (Halibozek ve Kovacich, 2005: 12).

Psikolojik Nedenler: İşletme birleşmelerinin en önemli nedenleri ekonomik nedenler olmasına rağmen psikolojik nedenler de birleşmelerin gerçekleştirilmesinde önemlidir. Kişinin yönetimsel veya finans alanındaki yeteneklerini gösterme arzusu, daha büyük bir organizasyonu yönetme tutkusu, hırsı, firmanın devamını emniyet altına alma duygusu, korku, demode olma kaygısı da birleşme kararında etkili olmaktadır (Akgüç, 1998: 869-870).

\section{2. İşletme Birleşmelerinin Türleri}

İşletme birleşmeleri literatürde değişik biçimlerde sınıflandırılmaktadır. En yaygın sınıflandırma biçimi olan ekonomik faaliyet alanlarına ve hukuki yapılarına göre işletme birleşmeleri aşağıdaki gibidir:

Şekil 2. İşletme Birleşmelerinin Türleri

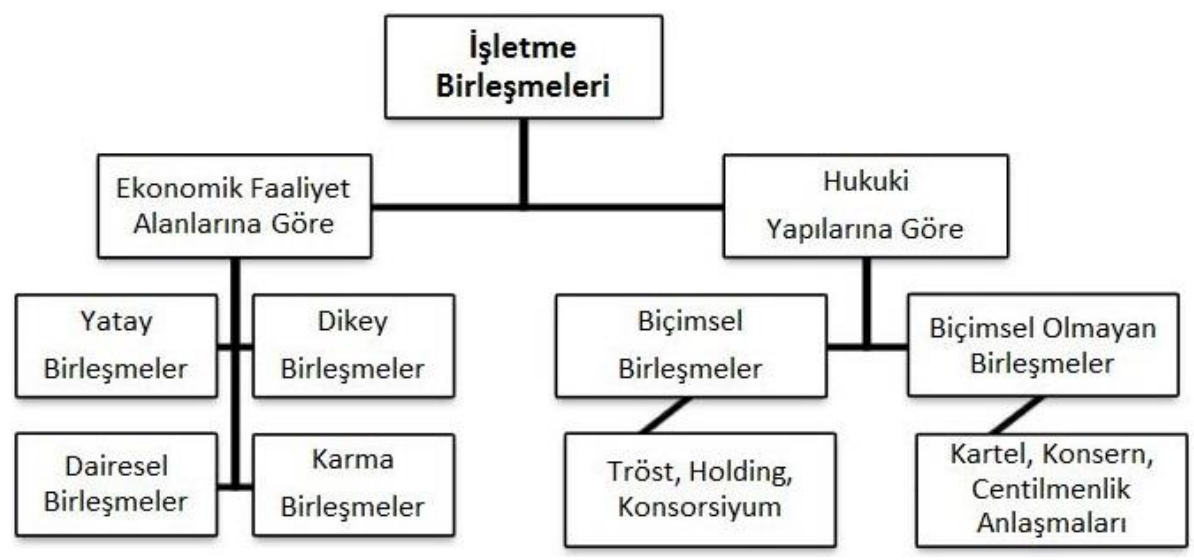

\subsubsection{Ekonomik Faaliyet Alanlarına Göre İşletme Birleşmeleri}

Ekonomik faaliyet alanlarına göre işletme birleşmeleri aşağıdaki gibi 4'e ayrılır:

Yatay Birleşmeler, bir şirketin faaliyette oldugu işkolunda yer alan rakip bir firma ya da firmalarla birleşmesidir (Eren, 2000: 77). İşletmeler yatay birleşme ile faaliyetlerini gerçekleştirdikleri sektörde pazar paylarını artracak şekilde büyüme gerçekleştirmektedir.

Dikey Birleşmeler, herhangi bir malın ya da hizmetin üretiminden satı̧ına kadar farklı aşamalarında faaliyette bulunan işletmeler arasında yapılan birleşmelerdir. Genelde bu tür birleşmelerde işletmeler arasında alıcı-satıcı ilişkisi ya da aynı ürünlerin farklı aşamalarında faaliyette bulunan işletmeler söz konusudur (Jhonson ve Bacon, 1982: 632). 
Dairesel Birleşmeler, aynı türe ait birleşmeler olarak da adlandırılmaktadır. Dairesel birleşmeler ürettikleri ürünler birbirleriyle ilişkili olmadığı halde, aynı dağıtım kanalını kullanan işletmelerin birleşmesiyle gerçekleştirilen birleşme şekli olup yatay birleşmelerle benzerlik göstermektedir (Baş, 1990: 50).

Karma Birleşmeler, birbirlerinden farklı ya da ilgisiz alanlarda faaliyet gösteren iki işletmenin birleşmesi olarak ifade edilmektedir. Karma birleşmelerde amaç, mali kaynakların daha etkin kullanılmasını sağlayarak sermaye maliyetini düşürmek, böylelikle hisse başına olan kazancı maksimum seviyeye çıkarmaktır (Aswathappa ve Keddy, 2010: 139).

\subsubsection{Hukuki Yapılarına Göre İşletme Birleşmeleri}

Hukuki yapılarına göre işletme birleşmeleri aşağıdaki gibi 6'ya ayrılır:

Tröst, iki veya daha fazla tüzel kişiliğe sahip işletmenin üretim ve satş konularında birlikte hareket etmek üzere anlaşmalarıdır. Tröst biçimindeki örgütlenmede işletmeler tüzel kişiliklerini kaybetmemektedir. Tröstler genellikle mali birleşmelere gitmekte, bu nedenle üye işletmelerin bağımsız karar alma yetkileri iyice kısıtlanmaktadır (Şahin, 1994: 194).

Holding, çağımızda en çok görülen örgütlenme biçimidir. Holding yoluyla bir grup meydana gelmekte ve bu yöntemle bir ana kuruluş çok sayıdaki işletmeyi kendi elinde tutmaktadır. Holding bünyesindeki işletmeler bir sektörde değil birçok sektörde faaliyet göstemektedir. Bu şekilde oluşan şirketler grubu, sermaye birikimi bakımından, yenilik bakımından ve baskı grubu olması bakımından büyük avantaj sağlamaktadır (Unay, 1997: 173).

Konsorsiyum, iki ya da daha fazla işletmenin belirli bir işi ya da projeyi gerçekleştirmek üzere aralarında geçici olarak yapttkları işbirliğidir (Babacan, 2012: 101). İşletmeler arasında konsorsiyum kurulmasının temel nedenleri arasında yeterli sermayeyi bulamama ve üstlenilen riski yayma düşüncesi yer alabilmektedir. Konsorsiyumlarda firmaların bir araya gelmesine sebep olan amaç gerçekleştirildiğinde konsorsiyum sona ermektedir (Can, 2000: 108).

Kartel, şirketler arasında sık rastlanan işbirliği şeklidir. Kartel, aynı üretim branşında çalışan şirketlerin rekabeti ortadan kaldırmak veya azaltmak amacıyla hukuksal varlıklarını koruyarak oluşturdukları işbirliğidir (Keskinoğlu, 1961: 8).

Konsern, az sayıda firmanın, daha yakın ilişkilerle bir araya gelerek karlarını artırmaya çalışmasıdır. Bu türde, hukuki bağımsızlık vardır ama iktisadi bağımsızlık ortadan kalkmaktadır. Zira, konserne giden şirketler amaçlarına ulaşmak için, pazar koşullarını doğrudan etkilemeye çalışmak yerine, teknik ve finansal yapılarını veya örgüt yapılarını daha elverişli hale getirmektedir. Üyeler arasında işbölümü yapılmakta ve iktisadi bağımsızlık ortadan kalkmaktadır (Mucuk, 2003: 50).

Centilmenlik Anlaşmaları, kişisel sözlü anlaşmalar (Gentlemen's Agreements), yazılı bir sözleşmeye dayanmadan belirli konularda işletmeler arasında gerçekleştirilen bir işbirliği türüdür. Karşılıklı güvene dayanan bu anlaşmalar genellikle rekabetin ortadan kaldırılması amacına yönelik olmaktadır (Müftüoğlu, 1989: 531).

\section{UFRS 3 Uyarınca İşletme Birleşmeleri}

\subsection{Standardın Tarihsel Gelişimi}

UFRS 3 İşletme Birleşmeleri standardının temelleri E 22 İşletme Birleşmelerinin Muhasebeleştirilmesi Taslak Metni'ne dayanmaktadır. Uluslararası Muhasebe Standartları Komitesi, Eylül 1981'de E 22 İşletme Birleşmelerinin Muhasebeleştirilmesi Taslak Metni (Exposure Draft E 22 Accounting for Business Combinations) yayınlayarak kamunun görüşüne sunmuştur. Gerçekleştirilen çalışmalar neticesinde Kasım 1983'te UMS 22 iş̧letme Birleşmelerinin Muhasebeleştirilmesi (IAS 22 Accounting for Business Combinations) standardı yayınlanmış ve 1 Ocak 1985 tarihinden itibaren uygulanmasına karar verilmiştir (Deloitte Touche Tohmatsu Limited, https://www.iasplus.com/en/standards/ias/ias22). Standart o tarihten günümüze kadar aşağıdaki değişikliklere uğramıştır: 
UFRS 3 İşletme Birleşmeleri Standardı Kapsamında Ters Iş̧letme Birleşmeleri ve Muhasebeleştirilmesi

Şekil 3. UFRS 3 Kronolojisi

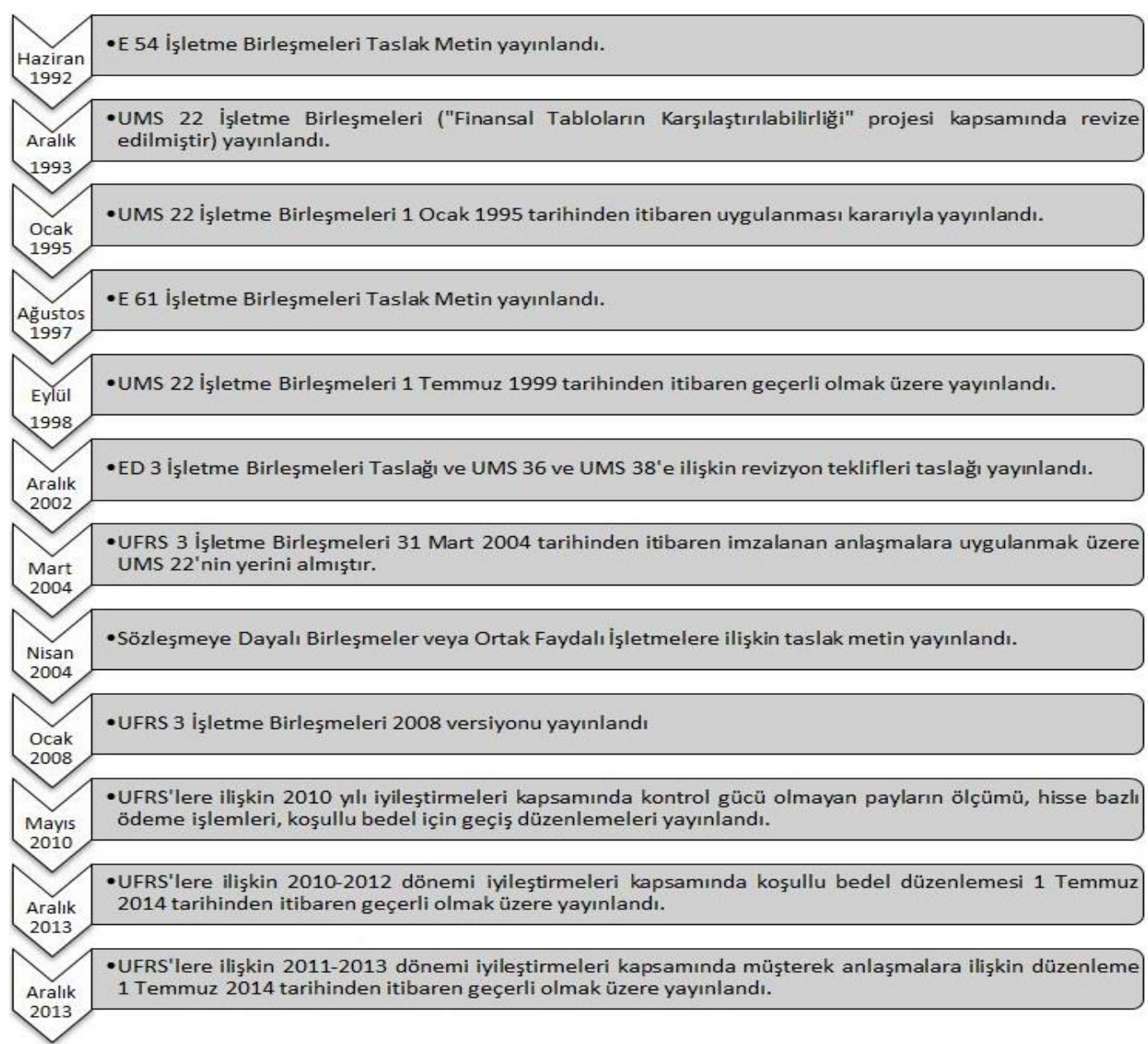

Kaynak: Deloitte Touche Tohmatsu Limited, https://www.iasplus.com

\subsection{Satın Alma Yöntemi}

UFRS 3 uyarınca bir işletme tüm işletme birleşmelerini satın alma yöntemini kullanarak muhasebeleştirmekle yükümlüdür (UFRS 3, m.4). Standardın beşinci maddesinde satın alma yönteminin adımları:

- Edinen işletmenin belirlenmesi,

- Birleşme tarihinin belirlenmesi,

- Edinilen tanımlanabilir varlıkların, üstlenilen tanımlanabilir borçların ve kontrol gücü olmayan payların (azınlık paylarının) finansal tablolara yansıtılması ve ölçülmesi ve

- Şerefiye veya pazarlıklı satın alma sonucunda oluşabilecek kazancın muhasebeleştirilmesi ve ölçülmesi

olarak sıralanmaktadır.

Grant Thornton Uluslararası Bağımsız Denetim ve Danışmanlık firmasının yapmış olduğu bir çalışmada yukarıdaki belirtilmiş olan süreç uygulamaya yönelik olarak bir miktar daha genişletilerek sunulmuştur: 
Şekil 4. UFRS 3 Uyarınca İşletme Birleşmelerinin İncelenmesi Süreci

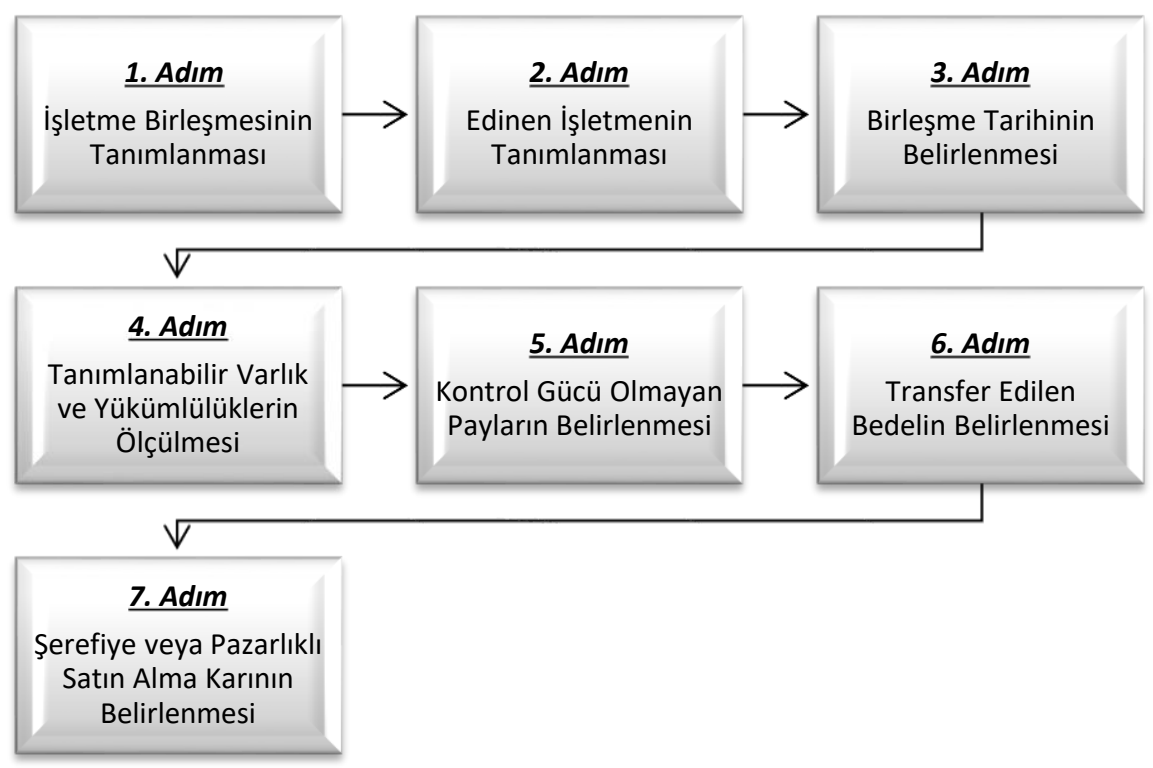

Kaynak: Grant Thornton LLP, Adviser alert: Navigating the accounting for business combinations - Applying IFRS 3 in practice, (Çevrimiçi), http://www.grantthornton.ca/resources/insights/adviser_alerts/GTI_IFRS_Na vigating_business_combinations.pdf

\subsection{1. İ̧̧letme Birleşmesinin Tanımlanması}

Standart uyarınca bir işletme birleşmesi bir edinen işletmenin, bir veya daha fazla işletmenin (edinilen işletme) kontrolünü eline geçirdiği bir işlem veya başka bir olay şeklinde tanımlanmaktadır (UFRS 3, Ek A). ílişkili olmayan bir işletme varlığındaki kontrol gücü edinimi gibi geleneksel satın alımların çoğu UFRS 3 kapsamında işletme birleşmeleri olarak kabul edilmektedir. Bununla birlikte, başka bir varlık veya varlık grubunun satın alımıyla ilgili işlemler sırasında UFRS 3 uygulaması adına aşağıdakilere cevap aranması gerekmektedir (Grant Thornton, 2011: 2):

- Edinilen şey bir işletmeyi mi teşkil eder?

- Kontrol elde edildi mi?

- Bu birleşme UFRS 3 kapsamında yer almakta mıdır?

\subsubsection{Edinen İşletmenin Tanımlanması}

UFRS 3'e göre edinen işletme edinilen işletmenin kontrolünü ele geçiren işletme olarak tanımlanmaktadır. UFRS 3, edinen işletmenin belirlenmesinde UFRS 10 Konsolide Finansal Tablolar standardında yer alan hükümlerin kullanılması gerektiğini belirtmektedir. Ancak gerçekleşen bir işletme birleşmesinde UFRS 10 hükümlerinin uygulanmasına rağmen birleşen işletmelerden hangisinin edinen işletme olduğunun belirlenemediği bir durum oluşması halinde UFRS 3'ün B14-B18 paragraflarındaki unsurlar göz önünde bulundurulmaktadır (UFRS 3, m.7).

\subsubsection{Birleşme Tarihinin Belirlenmesi}

Edinilen işletmenin satın alma yöntemine göre muhasebeleştirilmesinde esas alınan tarih, birleşme tarihidir. Buradaki birleşme tarihi, edinen işletmenin edinilen işletme üzerinde kontrolü elde ettiği (Holzmann ve Robinson, 2006: 75), başka bir ifade ile edinilen işletmenin net varlıkları ve faaliyetlerini kontrol etme gücünün edinen işletme tarafina geçtiği tarihtir (Harden vd., 2005: 1). 


\subsubsection{Tanımlanabilir Varlık ve Yükümlülüklerin Ölçülmesi}

UFRS 3 uyarınca edinen işletme birleşme tarihi itibarıyla edinilen tanımlanabilir varlıkları ve üstlenilen tanımlanabilir borçları birleşme tarihindeki gerçeğe uygun değerleri ile ölçmektedir (UFRS $3, \mathrm{~m} .18$ ). Tanımlanabilir varlık ve yükümlülüklerin ölçüm uygulamaları işletme birleşmesi işlemlerinin en karmaşık ve zaman alıcı adımıdır. İşletmeler bu adımda;

- Edinilen işletmenin finansal tablolarında muhasebeleştirilemeyen bazı maddi olmayan duran varlıklar da dahil olmak üzere edinilen tanımlanabilir varlıkların ve üstlenilen yükümlülüklerin tanımlanması,

- Edinilen tanımlanabilir varlıkların ve yükümlülüklerin gerçeğe uygun değerlerinin belirlenmesi,

- Gerekmesi halinde varlık ve yükümlülüklere ilişkin spesifik tanımlama ve ölçme hükümlerinin uygulanabilirliğinin belirlenmesi ve

- Edinilen varlık ve üstlenilen yükümlülüklerin düzenlenip sınıflandırılması

gibi işlemleri gerçekleştirmektedir (Kıymetli Şen vd., 2015: 41-42).

\subsubsection{Kontrol Gücü Olmayan Payların Belirlenmesi}

UFRS 10 Konsolide Finansal Tablolar standardı uyarınca kontrol gücü olmayan paylar, bir bağı ortaklığın doğrudan doğruya veya dolaylı olarak ana ortaklığa ait olmayan paylarıdır (UFRS 10, Ek A). Yatırım yapan işletme (ana ortaklık), yatırım yapılan işletmenin (bağlı ortaklık) hisse senetlerinin belirli bir kısmını satın aldığında, geri kalan hisse senetleri kontrol gücü olmayan payları bir başka deyişle azınlık paylarını temsil etmektedir (Aktaş, 2013: 154).

Şekil 5. Kontrol Gücü Olmayan Paylar

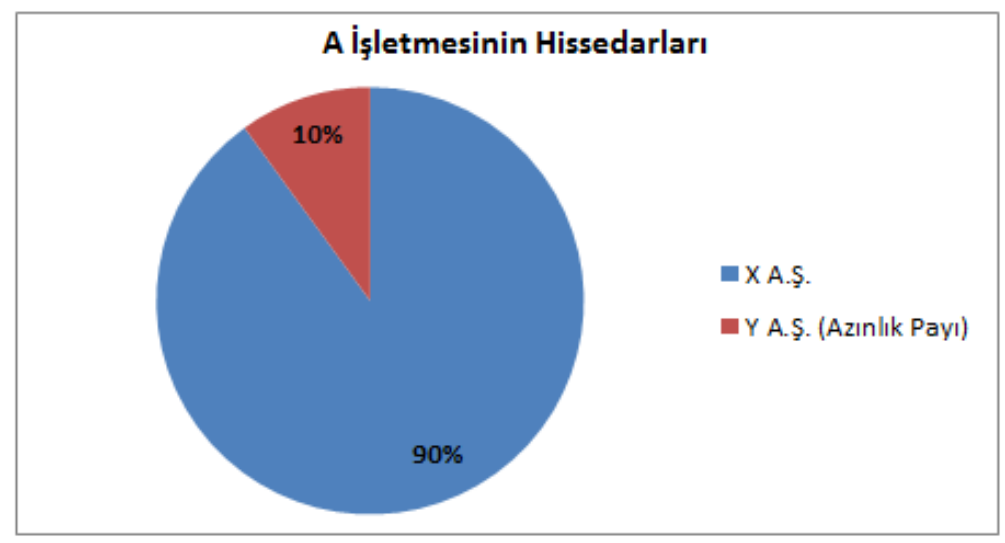

Yukarıdaki şekilde bir A işletmesinin ortaklık yapısı gösterilmiştir. Hissedarlardan X A.Ş. diğer etkenler göz ardı edildiğinde \%90 hisseye sahip olmasından ötürü kontrol sahibi (hakim) ortak olarak nitelendirilmektedir. Y A.Ş.'nin A işletmesindeki \%10 oranındaki payı normal şartlarda kontrol gücü sağlamayacaktır. X A.Ş. kendi konsolide finansal tablolarını hazırlarken sahip olduğu kontrol gücü nedeniyle bağlı ortaklığı olarak nitelendirilecek olan A işletmesinin hissedarlarından Y A.Ş.'ye ait payı konsolide finansal tablolarında kontrol gücü olmayan paylar kaleminde gösterecektir.

\subsubsection{Transfer Edilen Bedelin Belirlenmesi}

Transfer edilen bedel bir başka deyişle satın alma bedeli, edinilen işletme için ödenen/katlanılan tutarı ifade etmektedir (Özerhan ve Yanık, 2012: 563). Transfer edilen bedel nakit olabileceği gibi diğer varlıklar, edinen işletmenin bir işletmesi veya iştiraki, koşullu bedeller, sıradan veya imtiyazlı özkaynağa dayalı finansal araçlar, opsiyonlar, garantiler ve ortak faydalı işletmelerin üye hakları şeklinde de olabilmektedir. Bir işletme birleşmesinde transfer edilen bedel gerçeğe uygun değer ile ölçülmekte olup edinen işletme 
tarafindan transfer edilen varlıkların birleşme tarihindeki gerçeğe uygun değerlerinin, edinen işletme tarafindan edinilen işletmenin önceki sahiplerine karşı üstlenilen borçların ve edinen işletme tarafindan çıkarılan özkaynak paylarının toplamı olarak hesaplanacaktır (UFRS 3, m.37).

\subsection{7. Şerefiye veya Pazarlıklı Satın Alma Karının Belirlenmesi}

UFRS 3 uyarınca tek olarak tanımlanamayan ve ayrı olarak kaydedilemeyen bir işletme birleşmesinde edinilmiş diğer varlıklardan kaynaklanan gelecekteki ekonomik faydaya şerefiye adı verilmektedir (UFRS 3, Ek A). İşletme birleşmelerinde transfer edilen bedelin (satın alma bedeli) edinilen işletmenin tanımlanabilir net varlıklarının gerçeğe uygun değerlerini aşan kısmı "Şerefiye"; altında kalan kısmı "Pazarlıklı Satın Alma Karı" olarak muhasebeleştirilmektedir. Edinen işletme, şerefiye veya oluşması halinde pazarlıklı satın alma karını birleşme tarihi itibarıyla aşağıdaki şekilde gösterildiği gibi ölçerek muhasebeleştirmektedir:

Şekil 6. Şerefiye ve Pazarlıklı Satın Alma Karının Hesaplanışı

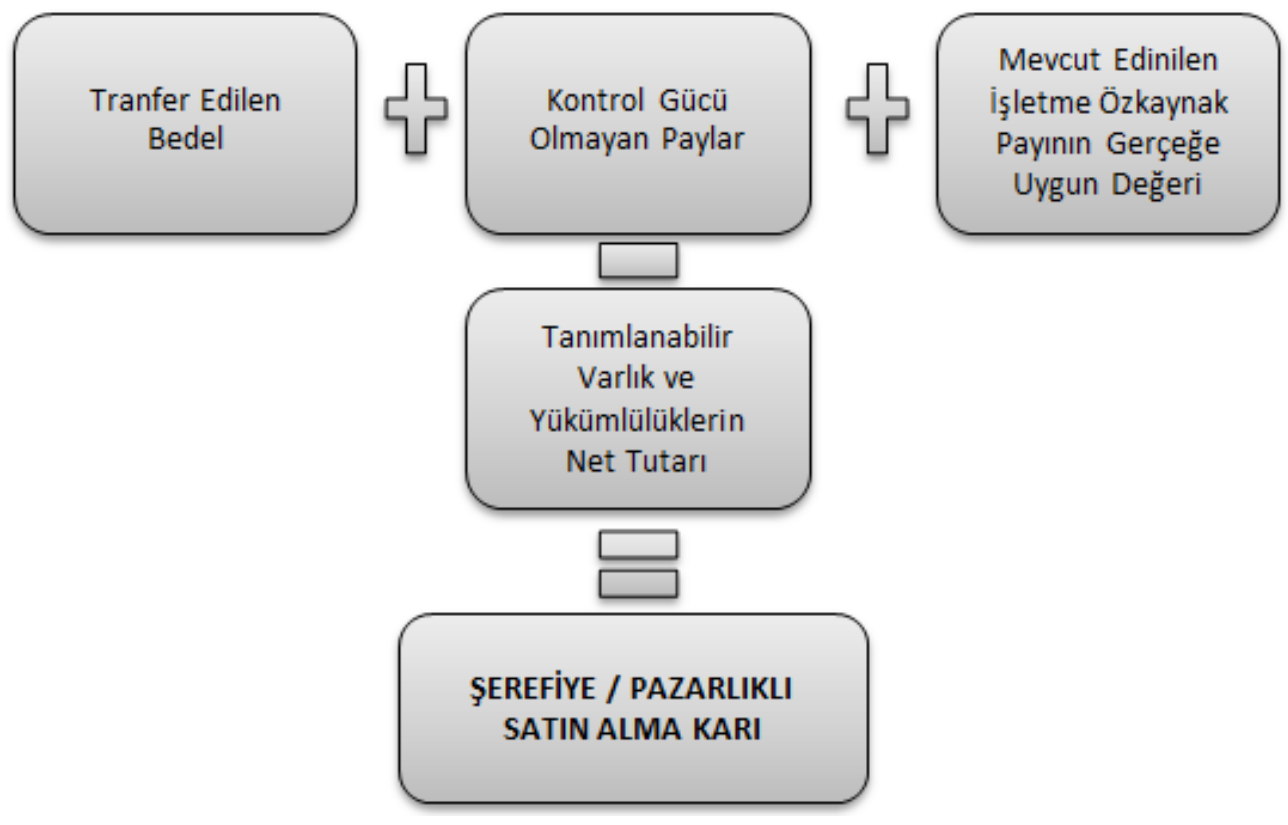

Yukarıdaki hesaplamanın neticesi pozitif bir değer olarak bulunursa bu tutar konsolide finansal durum tablosunda şerefiye olarak aktifleştirilmektedir. Pazarlıkı satın alma karı ise edinen işletmenin gelir tablosunda raporlanmaktadır.

\section{Ters İşletme Birleşmeleri}

\subsection{Ters İşletme Birleşmelerinin Tanımlanması}

Önceki bölümde UFRS 3 uyarınca işletme birleşmelerinde edinen ve edinilen işletmelerin tanımlaması yapılmıştır. Klasik işletme birleşmelerinde, işlemin taraflarından büyüklük olarak yüksek olanın edinen işletme olduğu kabul edilmektedir. Ancak kimi durumlarda bu durumun tersi ortaya çıkabilmekte, başka bir deyişle küçük işletmenin edinen işletme olarak tanımlandığı birleşme işlemleri oluşabilmektedir. Genellikle transfer edilen bedelin işlemin taraflarından birinin özkaynak aracı (hisse senedi gibi) ihracından oluştuğu işlemlerde bu gibi durumlar ortaya çıkmaktadır. Bu tarz işletme birleşmelerinde edinen ve edinilen işletmelerin belirlenmesi için birleşme işlemi neticesinde kontrol gücünün hangi işletmede kaldığının tespit edilmesi önem arz etmektedir. Kimi durumlarda edinen işletme ihraç edilmiş özkaynak araçlarını satın alan işletme, edinilen işletme ise özkaynak araçlarını ihraç eden işletme olarak belirlenmektedir. Başka bir deyişle birleşme işlemi sonrasında edinen işletmenin kontrolü özkaynak aracı ihracı nedeniyle edinilen işletmenin eline geçmektedir. Literatürde bu tip işletme birleşmesi işlemlerine "Ters İşletme Birleşmesi" adı verilmektedir. 
Standart bünyesinde ters işletme birleşmelerine ilişkin hükümler bulunmasına rağmen söz konusu işlemlerin muhasebeleştirilmesine ilişkin standardın yeterli açıklama getirmediği bir dizi sorun bulunmaktadır. Bunlar (Epstein ve Jermakowicz, 2010: 575-576);

- Hangi durumlar ters işletme birleşmesini işaret eder?

- Sonraki dönemlerde konsolide finansal tablolar nasıl sunulacaktır?

- Satnn alma bedeli nasıl hesaplanacaktır?

- İşlem sonrası özkaynak yapısı nasıl olacaktır?

- Hisse başına kazanç nasıl hesaplanacakttr?

- Kontrol gücü olmayan paylar nasıl sunulacaktrr?

şeklinde sıralanabilmektedir.

\subsection{Ters İşletme Birleşmelerinde Satın Alma Yöntemi}

Ters işletme birleşmelerinde de klasik işletme birleşmelerinde olduğu gibi UFRS 3 uyarınca satın alma yöntemi uygulanmaktadır. Çalışmanın önceki bölümünde klasik işletme birleşmelerinde satın alma yönteminin uygulanışı ile ilgili bilgi verilmiştir. Aşağıda ters işletme birleşmelerinde satın alma yönteminin uygulanışı detaylandırılacaktır.

\subsection{1. İşletme Birleşmesinin Tanımlanması}

Ters işletme birleşmeleri genellikle halka açık olup faaliyetleri kısıtlı olan bir işletme ile halka açılmak isteyen faaliyetleri geniş başka bir işletme arasında gerçekleşmektedir. Halka açılmak isteyen işletme normalde zaman ve para harcanması gereken bir süreci ters işletme birleşmesi sayesinde kolay bir şekilde tamamlamaktadır. Ancak ters işletme birleşmeleri sadece halka açılmak isteyen işletmelerin kullandığı bir yöntem değildir. íki halka açık veya halka açık olmayan işletme arasında da ters işletme birleşmeleri gerçekleşmektedir.

\subsubsection{Edinen İşletmenin Tanımlanması}

Ters işletme birleşmelerinde taraflar için kullanılan kavramlar klasik işletme birleşmelerinden ayrılmaktadır. Karşı tarafin hisselerini elde etmek için kendi hisselerini ihraç eden işletme yasal olarak bir işletme almış olmasından ötürü "Yasal Ana Ortaklık" olarak isimlendirilmektedir. Ancak aynı işletmenin ters işletme birleşmesi sonucunda oluşacak sahiplik oranının diğer işletmeden daha düşük olacak olmasından ötürü yasal ana ortaklık UFRS 3 uyarınca "Edinilen" işletme olarak nitelendirilecektir. Benzer şekilde hisselerine talip olunan işletme "Yasal Bağıı Ortaklık" olarak isimlendirilmektedir. Ancak aynı işletmenin ters işletme birleşmesi sonucunda oluşacak sahiplik oranının diğer işletmeden daha büyük olacak olmasından ötürü yasal bağlı ortaklık UFRS 3 uyarınca "Edinen” işletme olarak nitelendirilecektir.

\subsubsection{Birleşme Tarihinin Belirlenmesi}

Klasik işletme birleşmelerinde olduğu gibi ters işletme birleşmelerinde de birleşme tarihi, edinen işletmenin edinilen işletme üzerinde kontrolü elde ettiği, başka bir ifade ile edinilen işletmenin net varlıkları ve faaliyetlerini kontrol etme gücünün edinen işletme tarafina geçtiği tarihtir.

\subsubsection{Tanımlanabilir Varlık ve Yükümlülüklerin Ölçülmesi}

Klasik işletme birleşmelerinde yasal ana ortaklığın birleşme tarihi itibarıyla bağlı ortaklığın tanımlanabilir varlıkları ve üstlendiği tanımlanabilir borçları birleşme tarihindeki gerçeğe uygun değerleri ile ölçtüğü çalışmanın önceki bölümünde belirtilmişti. Konsolide perspektifle bakıldığında klasik işletme birleşmelerinde birleşme neticesinde sunulacak konsolide finansal tablolara yasal ana ortaklık bünyesindeki varlık ve yükümlülükler defter değerlerinden; bağlı ortaklık bünyesindeki varlık ve yükümlülükler ise gerçeğe 
uygun değerlerinden dahil olmaktadır. Ters işletme birleşmelerinde ise farklı bir uygulama söz konusudur. Bir ters işletme birleşmesi neticesinde sunulacak konsolide finansal tablolara yasal bağlı ortak (UFRS edinen) işletmenin varlık ve yükümlülükleri birleşme öncesi defter değerleri ile dahil olmaktadır. Yasal ana ortaklık (UFRS edinilen) işletmenin varlık ve yükümlülükleri ise konsolide finansal tablolarda gerçeğe uygun değerlerinden dahil olmaktadır.

\subsubsection{Kontrol Gücü Olmayan Payların Belirlenmesi}

Bir ters işletme birleşmesinde kontrol gücü olmayan paylar ancak yasal bağı ortaklığın hissedarlarından bir kısmının birleşme işlemine katılmaması ve dolayısıyla hissedarlık haklarının yasal bağlı ortaklık ile sınırı kalması halinde oluşmaktadır. Ancak kontrol gücü olmayan paylara sahip hissedarların muhasebe perspektifinden bakıldığında başka bir işletmeyi satın alan bir işletmenin hissedarları olduğu unutulmamalıdır. Başka bir deyişle kontrol gücü olmayan payları oluşturan hissedarların kimliği muhasebe perspektifiyle değil, birleşme işleminin hukuki yapısıyla belirlenmektedir. Yasal bağlı ortaklık (UFRS edinen) işletmenin net varlıklarının konsolide finansal tablolarda defter değerleri ile bulunmasından ötürü kontrol gücü olmayan paylara ilişkin yapılacak hesaplama yasal bağlı ortaklık (UFRS edinen) işletmenin net varlıkları üzerinden gerçekleştirilmektedir.

\subsubsection{Transfer Edilen Bedelin Belirlenmesi}

Nakite dayalı geleneksel işletme birleşmelerinde transfer edilen bedelin (satın alma bedeli) gerçeğe uygun değerinin tespiti ile ilgili genel kabul görmüş uygulama, işlem için edinen işletmenin edinilen işletme hissedarlarına ödediği bedelin kullanılmasıdır. Ters birleşmelerde ise transfer edilen bedelin gerçeğe uygun değerinin tespitinde farklı bir uygulama söz konusudur. Ters birleşmelerde eğer yasal ana ortaklık (UFRS edinilen) işletmenin beher hissesinin gerçeğe uygun değeri güvenilir şekilde ölçülebiliyorsa hesaplama bazı olarak kullanılabilmektedir. Yasal ana ortaklık, bir başka deyişle UFRS edinilen, işletmenin beher hissesinin gerçeğe uygun değerinin ölçülemediği durumlarda yasal bağlı ortaklık, bir başka deyişle ters birleşme uyarınca UFRS edinen, işletmenin beher hissesinin gerçeğe uygun değeri hesaplama bazı olarak kullanılmaktadır. Çalışmanın önceki bölümlerinde ters birleşme işlemlerinin genellikle halka açık olmayan işletmelerin halka açılmak için kullandığı belirtilmiştir. Halka açık işletmelerin hisselerinin gerçeğe uygun değerinin ölçümünün kolaylığından ötürü genel olarak ters birleşemelerde yasal bağlı ortaklık (UFRS edinilen), bir başka deyişle hisselerine sahip olmak için başka bir işletmenin kendi hisse senetlerini ihraç ettiği, işletmenin beher hissesinin gerçeğe uygun değeri kullanılmaktadır (Epstein ve Jermakowicz, 2010: 577).

Yasal bağlı ortaklık (UFRS edinen) işletmenin beher hissesinin gerçeğe uygun değerinin transfer edilen bedelin hesaplanmasında kullanıldığı durumlarda varsayımsal olarak hareket edilir. Bu varsayım, yasal bağlı ortaklık (UFRS edinen) işletme yasal ana ortaklık (UFRS edinilen) işletmenin hisselerini elde etmeyi amaçlasaydı birleşme sonrasında oluşacak konsolide şirkette aynı sahiplik oranına ulaşabilmek için yasal ana ortaklık (UFRS edinilen) işletme hissedarlarına kaç adet yeni hisse senedini ihraç etmesi gerektiğine dayanmaktadır. Hesaplanan hisse senedi adedine ilişkin gerçeğe uygun değer ters birleşme işleminin transfer edilen bedeli olarak kabul edilmektedir.

\subsection{7. Şerefiye veya Pazarlıkı Satın Alma Karının Belirlenmesi}

Eğer hesaplanan satın alma maliyeti edinilen işletmenin net varlıklarının gerçeğe uygun değerini aşıyor ise aşan kısım şerefiye olarak muhasebeleştirilmekte ve söz konusu şerefiye sonraki dönemlerde değer düşüklüğü açısından test edilmektedir. Eğer söz konusu tutar edinilen işletmenin net varlıklarının gerçeğe uygun değerinden daha düşük ise bu tutar pazarlıklı satın alma karı olarak finansal tablolara alınmaktadır.

Bir ters işletme birleşmesi neticesinde oluşan konsolide finansal tablolar yasal ana ortaklık adına hazırlanmaktadır. Ancak aynı finansal tablolar UFRS perspektifinden bakıldığında edinilen işletmenin varlık, yükümlülük, gelir ve giderlerinden oluşmaktadır. Başka bir deyişle ters işletme birleşmesi işlemi neticesinde UFRS uyarınca edinilen işletme edinen işletmenin devamını sağlamaktadır. Bu da ters işletme birleşmelerini klasik işletme birleşmelerinden ayıran bir başka önemli noktadır. 
Aşağıdaki tabloda klasik işletme birleşmeleri ile ters işletme birleşmeleri arasındaki temel farklar bir arada verilmiştir:

Tablo 1. Klasik İşletme Birleşmeleri ile Ters Birleşmelerin Karşılaştırılması

\begin{tabular}{|c|c|c|}
\hline & Klasik İşletme Birleşmeleri & Ters Birleşmeler \\
\hline $\begin{array}{l}\text { Konsolide finansal } \\
\text { tablolar }\end{array}$ & Yasal ana ortaklık adı altında sunulur. & $\begin{array}{l}\text { Yasal ana ortaklık adı altında sunulur ancak } \\
\text { dipnotlarda yasal bağlı ortaklığın finansal tablolarının } \\
\text { devamı olduğu belirtilir. }\end{array}$ \\
\hline Transfer edilen bedel & $\begin{array}{l}\text { Yasal ana ortaklığın katlandığı bedelin } \\
\text { gerçeğe uygun değerinden ölçülür. }\end{array}$ & $\begin{array}{l}\text { Yasal bağlı ortaklığın yasal ana ortaklığın hisselerini } \\
\text { elde etmeyi amaçladığı bir birleşme sonrasında } \\
\text { oluşacak konsolide şirkette aynı sahiplik oranına } \\
\text { ulaşabilmek için ihraç etmesi gerekecek hisselerin } \\
\text { gerçeğe uygun değerinden ölçülür. }\end{array}$ \\
\hline $\begin{array}{l}\text { Yasal bağlı ortaklığın net } \\
\text { varlıkları }\end{array}$ & Gerçeğe uygun değerden ölçülür. & Birleşme öncesi defter değerlerinden ölçülür. \\
\hline $\begin{array}{l}\text { Yasal ana ortaklığın net } \\
\text { varlıkları }\end{array}$ & $\begin{array}{l}\text { Birleşme öncesi defter değerlerinden } \\
\text { ölçülür. }\end{array}$ & Gerçeğe uygun değerden ölçülür. \\
\hline $\begin{array}{l}\text { Şerefiye / pazarlıklı satın } \\
\text { alma karı }\end{array}$ & $\begin{array}{l}\text { Transfer edilen bedel ile yasal bağı } \\
\text { ortaklığın tanımlanabilir net varlıkları } \\
\text { arasındaki fark olarak ölçülür. }\end{array}$ & $\begin{array}{l}\text { Transfer edilen bedel ile yasal ana ortaklığın } \\
\text { tanımlanabilir net varlıkları arasındaki fark olarak } \\
\text { ölçülür. }\end{array}$ \\
\hline $\begin{array}{l}\text { Konsolide birikmiş karlar } \\
\text { ve diğer özkaynak } \\
\text { kalemleri }\end{array}$ & Sadece yasal ana ortaklığı yansıtır. & Sadece yasal bağlı ortaklığı yansıtır. \\
\hline Konsolide sermaye & Yasal ana ortaklı̆ıın sermayesini yansıtır. & $\begin{array}{l}\text { Yasal bağlı ortaklığın birleşme öncesi sermayesi ile } \\
\text { yasal ana ortaklığın gerçeğe uygun değerinin toplamı } \\
\text { şeklinde ölçülür. }\end{array}$ \\
\hline $\begin{array}{l}\text { Yasal bağlı ortaklıktaki } \\
\text { kontrol gücü olmayan } \\
\text { paylar }\end{array}$ & $\begin{array}{l}\text { Yasal bağlı ortaklığın net tanımlanabilir } \\
\text { varlıklarındaki orantılı pay üzerinden veya } \\
\text { gerçeğe uygun değerlerinden ölçülür. }\end{array}$ & $\begin{array}{l}\text { Yasal bağı ortaklığın birleşme öncesi net } \\
\text { tanımlanabilir varlıklarındaki orantılı pay üzerinden } \\
\text { ölçülür. Gerçeğe uygun değer opsiyonu } \\
\text { bulunmamaktadır. }\end{array}$ \\
\hline Karşılaştırmalı sunum & Sadece yasal ana ortaklığı yansıtır. & $\begin{array}{l}\text { Sadece yasal bağlı ortaklığı yansıtır ancak yasal ana } \\
\text { ortaklığın sermayesini yansıtacak şekilde geriye } \\
\text { dönük olarak düzeltilir. }\end{array}$ \\
\hline $\begin{array}{l}\text { Cari dönem hisse başına } \\
\text { kazanç }\end{array}$ & $\begin{array}{l}\text { Konsolide kazanç üzerinden hesaplanır. } \\
\text { Ağırlıklı ortalama hisse senedi adedi } \\
\text { olması halinde yasal bağlı ortaklığın } \\
\text { birleşme sonrası ihraç ettiği hisse } \\
\text { senetleri kullanılarak hesaplanır. }\end{array}$ & $\begin{array}{l}\text { Konsolide kazanç üzerinden hesaplanır. Ağırlıklı } \\
\text { ortalama hisse senedi adedi yasal bağı ortaklığı } \\
\text { birleşme öncesi ağırıklı ortalama hisse senedi } \\
\text { adedinin birleşme oranı ile çarpımı ile olması halinde } \\
\text { yasal ana ortaklığın birleşme sonrası ihraç ettiği hisse } \\
\text { senetleri kullanılarak hesaplanır. }\end{array}$ \\
\hline $\begin{array}{l}\text { Hisse başına kazancın } \\
\text { karşılaştırmalı gösterimi }\end{array}$ & Sadece edinen işletmeyi yansıtır. & $\begin{array}{l}\text { Yasal bağlı ortaklığın kazancını yansıtır. Yasal bağlı } \\
\text { ortaklığın ağırlıklı ortalama hisse senetlerinin } \\
\text { birleşme oranı ile çarpımı ile hesaplanır. }\end{array}$ \\
\hline $\begin{array}{l}\text { Yasal ana ortaklığın solo } \\
\text { finansal tabloları }\end{array}$ & Sadece yasal ana ortaklığı yansıtır. & Sadece yasal ana ortaklığı yansıtır. \\
\hline
\end{tabular}

Kaynak: UFRS 3 iş̧letme Birleşmeleri, B 19-27.

\section{3. Örnek Uygulama}

Bu örnek uygulamada Alfa A.Ş., Beta A.Ş.'nin hisselerini elde etmeyi amaçlamaktadır. Alfa A.Ş. elde etmeyi amaçladığı hisselere ilişkin bedeli nakit olarak ödemeyecek olup ihraç edeceği yeni hisselerini Beta A.Ş.'nin hissedarlarının kontrolüne verecektir. İşlem sonunda oluşacak konsolide işletmede Beta A.Ş.'nin hissedarlarının sermaye payı çoğunluğu elde edecektir. Çoğunluğun Beta A.Ş.'de geçecek olmasından ötürü 
bu işlem bir ters birleşme olarak isimlendirilecek olup Alfa A.Ş. yasal ana ortaklık (UFRS edinilen); Beta A.Ş. yasal bağlı ortaklık (UFRS edinen) işletme olarak nitelendirilecektir. ${ }^{1}$

Şirketlerin birleşme tarihi olan 30 Eylül 2017 ve önceki yılsonu olan 31 Aralık 2016 tarihlerindeki bilançoları aşağıdaki gibidir:

\begin{tabular}{|l|r|r|}
\hline \multicolumn{1}{|c|}{$\begin{array}{c}\text { Alfa A.Ş. (Yasal Ana Ortaklık, UFRS Edinilen) } \\
\text { Bilanço (TL) }\end{array}$} & \multicolumn{1}{c|}{ 30 Eylül 2017} & \multicolumn{1}{c|}{$\mathbf{3 1}$ Aralık 2016} \\
\hline Dönen varlıklar & 1.200 .000 & 1.000 .000 \\
\hline Duran varlıklar & 1.900 .000 & 1.950 .000 \\
\hline Toplam Varlıklar & $\mathbf{3 . 1 0 0 . 0 0 0}$ & $\mathbf{2 . 9 5 0 . 0 0 0}$ \\
\hline Kısa vadeli yabancı kaynaklar & 400.000 & 350.000 \\
\hline Uzun vadeli yabancı kaynaklar & 700.000 & 800.000 \\
\hline Toplam Yükümlülükler & $\mathbf{1 . 1 0 0 . 0 0 0}$ & $\mathbf{1 . 1 5 0 . 0 0 0}$ \\
\hline Sermaye (100.000 adet adi hisse senedi) & 500.000 & 500.000 \\
\hline Birikmiş karlar & 1.500 .000 & 1.300 .000 \\
\hline Toplam Özkaynaklar & $\mathbf{2 . 0 0 0 . 0 0 0}$ & $\mathbf{1 . 8 0 0 . 0 0 0}$ \\
\hline
\end{tabular}

\begin{tabular}{|c|c|c|}
\hline $\begin{array}{c}\text { Beta A.Ş. (Yasal Bağlı Ortaklık, UFRS Edinen) } \\
\text { Bilanço (TL) }\end{array}$ & 30 Eylül 2017 & 31 Aralık 2016 \\
\hline Dönen varlıklar & 1.500 .000 & 2.500 .000 \\
\hline Duran varlıklar & 7.250 .000 & 5.500 .000 \\
\hline Toplam Varlıklar & 8.750 .000 & 8.000 .000 \\
\hline Kısa vadeli yabancı kaynaklar & 1.250 .000 & 1.000 .000 \\
\hline Uzun vadeli yabancı kaynaklar & 1.750 .000 & 2.000 .000 \\
\hline Toplam Yükümlülükler & 3.000 .000 & 3.000 .000 \\
\hline Sermaye (60.000 adet adi hisse senedi) & 1.200 .000 & 1.200 .000 \\
\hline Birikmiş karlar & 4.550 .000 & 3.800 .000 \\
\hline Toplam Özkaynaklar & 5.750 .000 & 5.000 .000 \\
\hline
\end{tabular}

Birleşme tarihinde Alfa A.Ş. ve Beta A.Ş. işletmelerinin beher hisselerinin ölçülebilen piyasa değeri ve gerçeğe uygun değeri aşağıdaki gibidir:

\begin{tabular}{|l|r|r|}
\hline Şirket & \multicolumn{1}{|c|}{$\begin{array}{c}\text { Piyasa Değeri } \\
\text { (TL) }\end{array}$} & \multicolumn{1}{c|}{$\begin{array}{c}\text { Gerçeğe Uygun } \\
\text { Değeri (TL) }\end{array}$} \\
\hline Alfa A.Ş. & 25 & Bulunmuyor \\
\hline Beta A.Ş. & Bulunmuyor & 105 \\
\hline
\end{tabular}

Alfa A.Ş.'nin birleşme tarihi olan 30 Eylül 2017'de maddi duran varlıklarının gerçeğe uygun değeri 2.500.000 TL olup diğer varlık ve yabancı kaynaklarının gerçeğe uygun değerleri defter değerlerine eşittir. Alfa A.Ş.'nin birleşme işlemi için Beta A.Ş.'nin hissedarlarına ihraç edeceği hisse senetleri ve birleşme sonrasında oluşacak konsolide işletmedeki ortaklık dağılımı aşağıdaki gibidir: 
Beta A.Ş.'nin birleşmeye konu hisse senedi adedi $(\alpha)$

Alfa A.Ş.'nin Beta A.Ş.'nin 1 adet hissesi için ihraç edeceği hisse senedi adedi ( $\beta$ )

Alfa A.Ş.'nin ihraç edeceği toplam hisse adedi $(\lambda=\alpha \times \beta)$

Alfa A.Ş.'nin birleşmeye konu hisse senedi adedi (б)

100.000

Birleşme sonrasında konsolide hisse senedi adedi $(\phi=6+\lambda)$

Alfa A.Ş.'nin sahiplik oranı (6 / ф)

$35,71 \%$

Beta A.Ş.'nin sahiplik oranı $(\lambda / \phi)$

$64,29 \%$

\section{Transfer edilen bedel}

Yukarıdaki örnekte yasal ana ortaklık (UFRS edinilen) işletme Alfa A.Ş.'nin beher hissesinin gerçeğe uygun değerinin tespit edilmediği görülmektedir. Ancak yasal bağı ortaklık (UFRS edinen) işletme Beta A.Ş.'nin beher hissesinin gerçeğe uygun değeri tespit edilmiştir. Buna göre varsayımsal olarak Beta A.Ş.'nin Alfa A.Ş. hisse senetlerini elde ederek işlem sonunda oluşacak konsolide işletmede aynı sahiplik oranına ulaşması için ihraç etmesi gereken hisse senedi sayısı ve akabinde ters birleşme işlemine ilişkin transfer edilen bedel aşağıdaki gibi hesaplanmaktadır:

Beta A.Ş. hissedarları için Alfa A.Ş. tarafından ihraç edilen hisse senedi adedi $(\alpha)$

180.000

Alfa A.Ş.'nin birleşme öncesi hisse senedi adedi $(\beta)$

100.000

Birleşme sonrasında konsolide hisse senedi adedi $(\lambda=\alpha+\beta)$

280.000

Beta A.Ş. hissedarlarının birleşme sonrası sahiplik oranı $(\phi=\alpha / \lambda)$

$64,29 \%$

Beta A.Ş.'nin birleşmeye konu hisse senedi adedi $(\mu)$

Beta A.Ş.'nin Alfa A.Ş. hisselerini elde ettiğinde oluşacak konsolide işletmede aynı sahiplik oranına $(\% 64,29)$ ulaşması için ihraç etmesi gereken hisse senetleri $(4=\mu \times \beta$ /

a)

Beta A.Ş.'nin beher hissesinin gerçeğe uygun değeri (TL) $(\Omega)$

Transfer edilen bedelin gerçeğe uygun değeri $(\mathrm{TL})(Ч \times \Omega)$

Yukarıdaki hesaplamaya göre varsayımsal olarak Beta A.Ş., Alfa A.Ş.'nin 100.000 adet hissesini elde edip aynı zamanda \%64,29 olan sahiplik oranına ulaşması için 33.333 adet hisse senedi ihraç etmesi gerekeceği görülmektedir. Bu hisse senetlerinin gerçeğe uygun değer toplamı olan 3.500.000 TL de ters birleşme işlemine ilişkin transfer edilen bedel olarak kabul edilmektedir.

\section{Şerefiye}

UFRS 3 uyarınca işletme birleşmelerinde edinen işletme edinilen işletmenin net varlıklarının gerçeğe uygun değerlerini tespit etmektedir. Gerçeğe uygun değer tespit işlemi esasen edinen işletmenin edinilen işletmenin kontrolünü ele geçirmek için katlandığı bedelin söz konusu net varlıklara bölüştürülmesidir. Bu işleme "Satın Alma Fiyatının Dağıtımı (Purchase Price Allocation)" ismi verilmektedir. Dağıtım sonrası kalan tutar şerefiye olarak kayıtlara alınmaktadır. Yukarıda hesaplanan 3.500.000 TL tutarındaki transfer edilen bedel yasal ana ortaklık/UFRS edinilen Alfa A.Ş.'nin tanımlanabilir varlık ve yükümlülüklerine aşağıdaki şekilde dağıtılarak şerefiye hesaplanmaktadır:

Dönen varlıklar

Duran varlıklar ${ }^{2}$

Toplam Varlıklar $(\alpha)$

Kısa vadeli yabancı kaynaklar

Uzun vadeli yabancı kaynaklar

Toplam Yükümlülükler ( $\beta$ )
1.200 .000

2.500 .000

3.700 .000

400.000

700.000

1.100 .000 


\section{Konsolidasyon}

Yukarıdaki bilgilerden hareketle 30 Eylül 2017 tarihli ters birleşme işlemine ilişkin konsolide bilanço aşağıdaki gibi hazırlanmaktadır:

\begin{tabular}{|c|c|c|c|c|c|}
\hline $\begin{array}{l}\text { Alfa A.Ş. Konsolide Bilanço } \\
30 \text { Eylül } 2017 \text { (TL) }\end{array}$ & Alfa A.Ş. & Beta A.Ş. & Kombine & $\begin{array}{l}\text { Konsolidasyon } \\
\text { Düzeltmesi }\end{array}$ & Konsolide \\
\hline Dönen varlıklar & 1.200 .000 & 1.500 .000 & 2.700 .000 & - & 2.700 .000 \\
\hline Duran varlıklar & 1.900 .000 & 7.250 .000 & 9.150 .000 & 600.000 & 9.750 .000 \\
\hline Şerefiye & - & - & - & 900.000 & 900.000 \\
\hline Toplam Varlıklar & 3.100 .000 & 8.750 .000 & 11.850 .000 & 1.500 .000 & 13.350 .000 \\
\hline Kısa vadeli yabancı kaynaklar & 400.000 & 1.250 .000 & 1.650 .000 & - & 1.650 .000 \\
\hline $\begin{array}{l}\text { Uzun vadeli yabancı } \\
\text { kaynaklar }\end{array}$ & 700.000 & 1.750 .000 & 2.450 .000 & - & 2.450 .000 \\
\hline Toplam Yükümlülükler & 1.100 .000 & 3.000 .000 & 4.100 .000 & - & 4.100 .000 \\
\hline Sermaye & 500.000 & 1.200 .000 & 1.700 .000 & 3.000 .000 & 4.700 .000 \\
\hline Birikmiş karlar & 1.500 .000 & 4.550 .000 & 6.050 .000 & $(1.500 .000)$ & 4.550 .000 \\
\hline Toplam Özkaynaklar & 2.000 .000 & 5.750 .000 & 7.750 .000 & 1.500 .000 & 9.250 .000 \\
\hline \multicolumn{4}{|c|}{ Hesap } & Borç & Alacak \\
\hline Duran varlıklar & & & & 600.000 & \\
\hline Şerefiye & & & & 900.000 & \\
\hline \multirow[t]{2}{*}{ Birikmiş karlar } & & & & 1.500 .000 & \\
\hline & & & Sermaye & & 3.000 .000 \\
\hline
\end{tabular}

Yukarıda Alfa A.Ş.'nin duran varlıklarının gerçeğe uygun değerinin 2.500.000 TL olduğu belirtilmiştir. Konsolidasyon kaydındaki 600.000 TL duran varlıkların defter değerleri ile gerçeğe uygun değerleri arasındaki farktır (2.500.000 - 1.900.000). Konsolide finansal tablolarda gösterilen sermaye tutarı yasal bağlı ortaklığın birleşme öncesi sermayesi (100.000 adet hisse - 1.200.000 TL) ile transfer edilen bedelin gerçeğe uygun değerinin (180.000 adet hisse - 3.500.000 TL) toplamından oluşmaktadır. Hesaplamada varsayımsal olarak Beta A.Ş.'nin ihraç etmesi gereken hisse senedi adedinin kullanılmış olması okuyucuyu yanıltmamalıdır. Fiilen bu fiyat 180.000 adet Alfa A.Ş. hissesinin fiyatıdır. Bu tutara ulaşmak için kombine sermaye tutarına 3.000.000 TL eklenmektedir. Birikmiş karların ise edinen işletmenin birleşme öncesi birikmiş kar tutarını yansıtması gerektiğinden edinilen işletmenin 1.500.000 TL tutarlı birikmiş karları elimine edilmelidir.

\section{Hisse başına kazanç}

31 Aralık 2017 tarihinde sona eren döneme ilişkin konsolide kazancın 1.500.000 TL olduğu varsayılırsa bu tutar Beta A.Ş.'nin 2017 yılındaki tüm kazancı ile Alfa A.Ş.'nin birleşme tarihi olan 30 Eylül 2017'den yıl sonuna kadar olan kazancını içerecektir. Birleşme sonrası oluşan şirketin unvanının Alfa A.Ş. olmasına rağmen muhasebe açısından bu şirketin Beta A.Ş. olduğu unutulmamalıdır. Buna göre hisse başına kazanç aşağıdaki gibi hesaplanmaktadır: 
Birleşme tarihinden önce mevcut hisse senedi (Alfa A.Ş.'nin Beta A.Ş.'ye ihraç ettiği hisse senetleri) adedi ( $\beta$ )

Ters birleşme işlemlerinde ortalama hisse senedi adedi hesaplamasında birleşme işleminin gerçekleştiği yıl başlangıcından birleşme tarihine kadarki dönemdeki hisse senedi adedi olarak yasal ana ortaklık (UFRS edinilen) işletmenin yasal bağlı ortaklık (UFRS edinen) işletmenin hissedarlarına ihraç ettiği hisse senetleri temel alınmaktadır. Birleşme tarihinden yıl sonuna kadar olan dönemdeki hisse senedi adedi olarak ise konsolide işletmenin hisse senetleri kullanılmaktadır. Hisse başına kazancın raporlanmasına konu döneme ilişkin mevcut hisse senetlerinin belirlenmesi sırasında hisse senetlerinin yapısı ve sayısındaki değişiklikler dikkate alınmalıdır. Bu noktada önceki yıllardaki hisse başına kazancın mevcut yılla karşılaştırmalı olarak nasıl gösterileceği sorusu ortaya çıkmaktadır. Beta A.Ş.'nin 31 Aralık 2016 tarihinde sona eren döneme ilişkin kazancının 1.500 .000 olduğu varsayılırsa hisse başına kazanç şu şekilde hesaplanacaktır:

Birleşmeden önce mevcut hisse senedi adedi $(\alpha)$

\section{Kontrol gücü olmayan paylar}

Yukarıdaki örnekte Beta A.Ş.'nin 55.000 adet hisseye sahip hissedarının birleşme işlemine dahil olduğu, başka bir deyişle birleşme sonrasında 5.000 adet hisselik kontrol gücü olmayan pay oluştuğu varsayılırsa Alfa A.Ş.'nin birleşme işlemi için Beta A.Ş.'nin hissedarlarına ihraç edeceği hisse senetleri ve birleşme sonrasında oluşacak konsolide işletmedeki ortaklık dağılımı aşağıdaki gerçekleşecektir:

Beta A.Ş.'nin birleşmeye konu hisse senedi adedi $(\alpha)$

Alfa A.Ş.'nin Beta A.Ş.'nin 1 adet hissesi için ihraç edeceği hisse senedi adedi ( $\beta$ )

Alfa A.Ş.'nin ihraç edeceği toplam hisse adedi $(\lambda=\alpha \times \beta)$

Alfa A.Ş.'nin birleşmeye konu hisse senedi adedi (б)

Önceki durumda Alfa A.Ş. Beta A.Ş.'nin her 1 adet hissesi için 3 adet hisse ihraç etmiştir. Yani 180.000 adet Alfa A.Ş. hissesi 60.000 adet Beta A.Ş. hissesi ile el değiştirmiştir. 5.000 adet hisseye sahip Beta A.Ş. hissedarının birleşme işlemine katılmadığında Alfa A.Ş. kalan 55.000 adet Beta A.Ş. hissesi için 165.000 adet hisse ihraç edecektir. İşlem sonrasında Beta A.Ş.'nin hissedarları Alfa A.Ş.'nin toplam 265.000 adet hissesinin 165.000 adedine, başka bir deyişle \%62,26'sına sahip olacak ve çoğunluk hisseleri yine Beta A.Ş.'de olacağından dolayı bu durum bir kez daha bir ters işletme birleşmesi olarak nitelendirilecektir.

Transfer edilen bedel yine benzer şekilde hesaplanacaktır. Buna göre varsayımsal olarak Beta A.Ş.'nin Alfa A.Ş. hisse senetlerini elde ederek işlem sonunda oluşacak konsolide işletmede aynı sahiplik oranına 
ulaşması için ihraç etmesi gereken hisse senedi sayısı ve akabinde ters birleşme işlemine ilişkin transfer edilen bedel aşağıdaki gibi hesaplanmaktadır:

Beta A.Ş. hissedarları için Alfa A.Ş. tarafından ihraç edilen hisse senedi adedi $(\alpha)$

Alfa A.Ş.'nin birleşme öncesi hisse senedi adedi $(\beta)$

Birleşme sonrasında konsolide hisse senedi adedi $(\lambda=\alpha+\beta)$

Beta A.Ş. hissedarlarının birleşme sonrası sahiplik oranı $(\phi=\alpha / \lambda)$

Beta A.Ş.'nin birleşmeye konu hisse senedi adedi $(\mu)$

Beta A.Ş.'nin Alfa A.Ş. hisselerini elde ettiğinde oluşacak konsolide işletmede aynı sahiplik oranına $(\% 62,26)$ ulaşması için ihraç etmesi gereken hisse senetleri $(4=\mu \times \beta$

/ $\alpha)$

Beta A.Ş.'nin beher hissesinin gerçeğe uygun değeri (TL) $(\Omega)$

Transfer edilen bedelin gerçeğe uygun değeri $(T L)(५ \times \Omega)$

Yukarıdaki hesaplama neticesinde kontrol gücü olmayan payların bulunması halinde de transfer edilen bedelin gerçeğe uygun değerinin değişmediği görülmektedir. Şerefiye hesaplaması ise şu şekilde gerçekleştirilecektir:

\begin{tabular}{|l|r|}
\hline Dönen varlıklar & 1.200 .000 \\
\hline Duran varlıklar & 2.500 .000 \\
\hline Toplam Varlıklar $(\boldsymbol{\alpha})$ & 3.700 .000 \\
\hline Kısa vadeli yabancı kaynaklar & 400.000 \\
\hline Uzun vadeli yabancı kaynaklar & 700.000 \\
\hline Toplam Yükümlülükler $(\boldsymbol{\beta})$ & $\mathbf{1 . 1 0 0 . 0 0 0}$ \\
\hline Net Varlıklar $(\boldsymbol{\lambda}=\boldsymbol{\alpha}-\boldsymbol{\beta})$ & $\mathbf{2 . 6 0 0 . 0 0 0}$ \\
\hline Satın alma bedeli $(\boldsymbol{\phi})$ & 4.000 .000 \\
\hline Şerefiye $(\boldsymbol{\phi}-\boldsymbol{\lambda})$ & $\mathbf{1 . 4 0 0 . 0 0 0}$ \\
\hline
\end{tabular}

Yukarıda görüldüğü üzere şerefiye tutarında da herhangi bir değişiklik olmamaktadır. Buna göre konsolide bilanço aşağıdaki gibi hazırlanacaktır: 


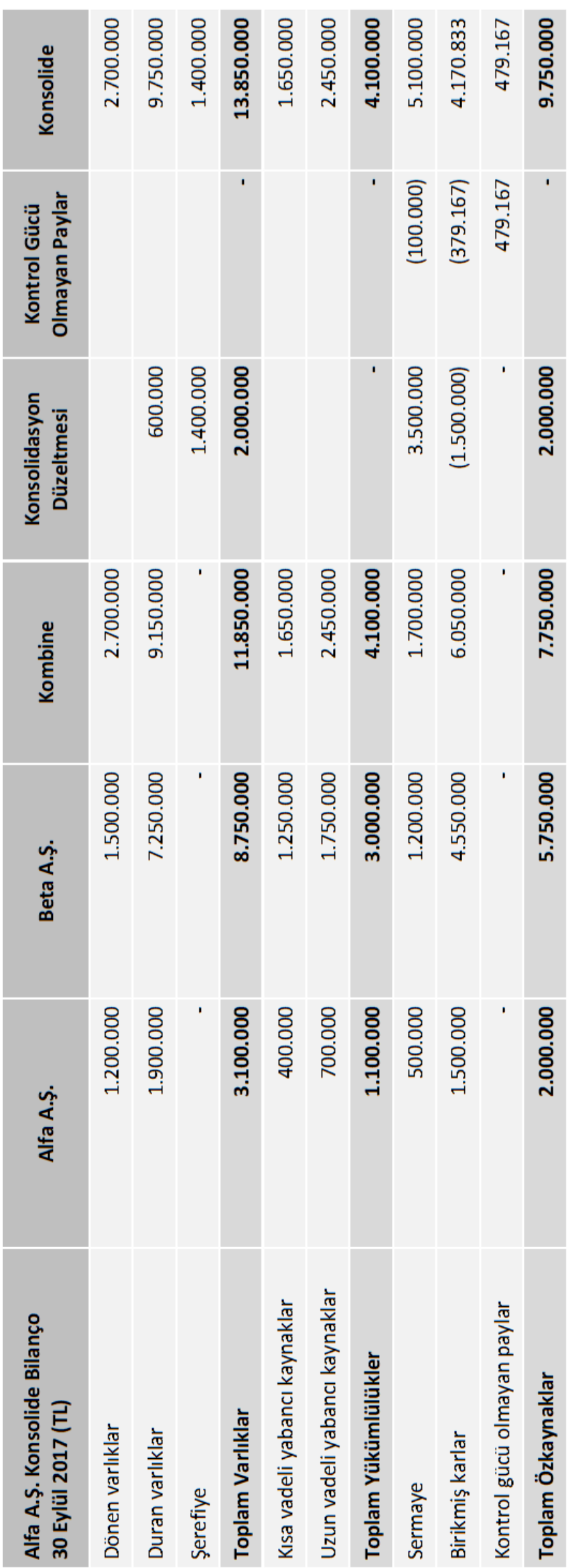


Konsolide bilançonun oluşturulması sırasında aşağıdaki kayıtlar gerçekleştirilmiştir:

\begin{tabular}{|c|c|c|c|}
\hline & Hesap & Borç & Alacak \\
\hline Duran varlıklar & & 600.000 & \\
\hline Şerefiye & & 1.400 .000 & \\
\hline \multirow[t]{2}{*}{ Birikmiş karlar } & & 1.500 .000 & \\
\hline & Sermaye & & 3.500 .000 \\
\hline \multicolumn{4}{|c|}{ Konsolidasyon düzeltmesi } \\
\hline & Hesap & Borç & Alacak \\
\hline Sermaye & & 100.000 & \\
\hline Birikmiş karlar & & 379.167 & \\
\hline & Kontrol gücü olmayan paylar & & 479.167 \\
\hline
\end{tabular}

Konsolide finansal tablolarda kontrol gücü olmayan paylara tekabül eden tutarlar aşağıdaki gibi hesaplanmıştr:

\begin{tabular}{|l|r|}
\hline Beta A.Ş.'nin birleşmeye konu olmayan hisse senedi adedi $(\alpha)$ & 5.000 \\
\hline Beta A.Ş.'nin toplam hisse senedi adedi $(\beta)$ & 60.000 \\
\hline Kontrol gücü olmayan pay oranı $(\lambda=\alpha / \beta)$ & $8,33 \%$ \\
\hline Sermaye (60.000 adet adi hisse senedi) $(\phi)$ & 1.200 .000 \\
\hline Sermayeden kontrol gücü olmayan paylara düşen tutar $(\mu=\phi \times \lambda)$ & 100.000 \\
\hline Birikmiş karlar (Ч) & 4.550 .000 \\
\hline Birikmiş karlardan kontrol gücü olmayan paylara düşen tutar $(\Omega=4 \times \lambda)$ & 379.167 \\
\hline Toplam kontrol gücü olmayan paylara düşen tutar $(\Omega+\mu)$ & $\mathbf{4 7 9 . 1 6 7}$ \\
\hline
\end{tabular}

\section{Sonuç}

Ters işletme birleşmeleri UFRS 3 içerisinde ayrı bir başlık altında incelenmiştir. Klasik işletme birleşmeleri ile muhasebeleştirme açısından farklı uygulamalara tabi olması ters işletme birleşmelerinin standart içerisinde ayrı bir başlıkta incelenmiş olmasının doğru bir yaklaşım olduğunu ortaya koymaktadır. Ters işletme birleşemelerinde karşı tarafin hisselerini elde etmeyi amaçlayan işletme bu işlem için katlanacağı bedeli ihraç ettiği kendi hisseleri ile karşıladığından "Yasal Ana Ortaklık" olarak isimlendirilmektedir. Ancak yasal ana ortaklık, ters işletme birleşmesi sonucunda oluşacak sahiplik oranının diğer işletmeden daha düşük olacak olmasından ötürü, UFRS 3 uyarınca "Edinilen" işletme olarak nitelendirilecektir. Benzer şekilde hisselerine talip olunan işletme "Yasal Bağlı Ortaklık" olarak isimlendirilmektedir. Ancak aynı işletmenin ters işletme birleşmesi sonucunda oluşacak sahiplik oranının diğer işletmeden daha büyük olacak olmasından ötürü yasal bağlı ortaklık UFRS 3 uyarınca "Edinen" işletme olarak nitelendirilmektedir. Ters işletme birleşmelerine ilişkin muhasebe uygulamalarının klasik işletme birleşmelerinden farklılık göstermesinin temeli buna dayanmaktadır.

Bir ters işletme birleşmesi neticesinde oluşan konsolide finansal tablolar yasal ana ortaklık adı altında sunulmaktadır. Ancak aynı finansal tablolar UFRS perspektifinden bakıldığında edinilen işletmenin varlık, yükümlülük, gelir ve giderlerinden oluşmaktadır. Başka bir deyişle ters işletme birleşmesi işlemi neticesinde UFRS uyarınca edinilen işletme edinen işletmenin devamını sağlamaktadır. Bu nedenle dipnotlarda yasal bağı ortaklığın finansal tablolarının devamı olduğu belirtilmektedir. Klasik işletme birleşmelerinde transfer edilen bedel yasal ana ortaklığın katlandığı bedelin gerçeğe uygun değerinden ölçülmekte iken ters işletme birleşmelerinde varsayımsal olarak hareket edilir. Bu varsayım, yasal bağlı ortaklık (UFRS edinen) işletme yasal 
ana ortaklık (UFRS edinilen) işletmenin hisselerini elde etmeyi amaçlasaydı birleşme sonrasında oluşacak konsolide şirkette aynı sahiplik oranına ulaşabilmek için yasal ana ortaklık (UFRS edinilen) işletme hissedarlarına kaç adet yeni hisse senedini ihraç etmesi gerektiğine dayanmaktadır. Hesaplanan hisse senedi adedine ilişkin gerçeğe uygun değer ters birleşme işleminin transfer edilen bedeli olarak kabul edilmekte ve muhasebeleştirilmektedir. Klasik işletme birleşmelerinde yasal bağlı ortaklığın net varlıkları gerçeğe uygun değerden, yasal ana ortaklığın net varlıkları defter değerlerinden ölçülürken ters işletme birleşmelerinde yasal ana ortaklığın net varlıkları gerçeğe uygun değerden, yasal bağlı ortaklığın net varlıkları defter değerlerinden ölçülerek muhasebeleştirilmektedir. Ters işletme birleşmelerinde şerefiye veya pazarlıklı satın alma karı hesaplaması yapılırken transfer edilen bedel ile yasal ana ortaklığın tanımlanmış net varlıklarının gerçeğe uygun değeri karşılaştırılırken klasik işletme birleşmelerinde bu işlem yasal bağlı ortaklığın varlık ve yükümlülükleri karşılaştırılarak muhasebeleştirme gerçekleştirilir.

Bu çalışmada ters işletme birleşmelerin UFRS 3 uyarınca muhasebeleştirme işlemlerinin klasik işletme birleşmelerinden yukarıda sayılan ve çalışma içerisinde belirtilen farklarının teorik olarak açıklanarak pratik uygulama ile pekiştirilmesi ve çalışmanın uygulayıcılar için referans bir kaynak olarak sunulması amaçlanmıştir.

\section{Son Notlar}

1. Uygulama ile ilgili olarak Wiley Interpretation and Application of Financial Reporting Standards kaynağından yararlanılmıştır.

2. Duran varlıkların gerçeğe uygun değerinin 2.500 .000 TL olduğu örneğin açıklama kısmında belirtilmiştir.

3. 1 Ocak - 30 Eylül 2017 dönemi 9 ay; 30 Eylül - 31 Aralık 2017 dönemi 3 ay olduğu için ortalama hisse senedi hesabı bu şekilde gerçekleştirilir.

\section{Kaynaklar}

Akgüç, Ö. (1998). Finansal yönetim. İstanbul: Muhasebe Enstitüsü Eğitim ve Araştırma Vakfı Yayını.

Aktaş, R. (2013). Illke temelli finansal raporlama standartları nasıl öğretilmeli? TFRS 10 konsolide finansal tablolar standardı örneği. Mali Çözüm Dergisi, 115, Ocak - Şubat, 133-168.

Aswathappa, K., \& Keddy, S. (2010). Strategic management: Concepts and cases. Bombay: Global Media.

Ataman, Ü. (2000). Şirketler muhasebesi. İstanbul: Türkmen Kitabevi.

Aydın, N. (1990). İşletmelerin birleşmesinde finansal analiz ve bir uygulama örneği. Ankara: Türkiye Odalar ve Borsalar Birligi Yayını.

Babacan, M. (2012). Ilkeler ve işlevlerle işletme. Ankara: Detay Yayıncılık.

Baker, R., Christensen, T., \& Cottrell, D. (2011). Advanced financial accounting. New York: McGraw-Hill.

Baş, M. i. (1990). İşletme birleşmelerine finansal bir bakış: Özellikle birleşmeler. Verimlilik Dergisi, 1, 43-72.

Brigham, E. (2006). Finansal yönetimin temelleri. Cilt 2, Çeviren: Akmut, Ö. ve Sarıhasan, H., Ankara: Ankara Üniversitesi Rektörlüğü Yayınları.

Brusco, S., Lopomo, G., \& Viswanathan, S. (2004). Merger mechanisms. Econometric Society 2004 North American Winter Meetings 317, s. 2, http://www.stonybrook.edu/commcms/economics/research/papers/2004/04-02.pdf, Erişim: 30.10.2016).

Can, H., Tuncer, D., \& Ayhan, D. (2000). Genel işletmecilik bilgileri. Ankara: Siyasal Kitabevi.

Çelen, A. (2010). Yatay yoğunlaşmaların tek tarafı etkilerinin belirlenmesinde talep tahmini ve simülasyon tekniklerinin uygulanması. Ankara: Rekabet Kurumu.

Deloitte Touche Tohmatsu Limited, IAS Plus. (Çevrimiçi) www.IASplus.com, (Erişim: 02.01.2017).

Epstein, B., \& Jermakowicz, E. (2010). Interpretation and application of International Financial Reporting Standards. New Jersey: John Wiley \& Sons. 
Eren, E. (2000). Stratejik yönetim ve işletme politikası. İstanbul: Beta Yayınları.

Grant Thornton LLP, Adviser Alert, (2011). Navigating the Accounting for Business Combinations, Applying IFRS 3 in Practice.

Griffin, C., Williams, T., \& Larson, K. (1980). Advanced accountin. Illinois: Irwin Publications.

Grinblatt, M., \& Titman, S. (2002). Financial markets and corporate strategy. Boston: McGraw Hill Companies.

Halibozek, E., \& Kovacich, G. (2005). Mergers and acquisitions security: Corporate restructuring and security management. Burlington: Butterworth-Heinemann.

Harden, S., Chiu, K., \& Valdez, F.F. (2005). Business combinations requiring the acquisition method. California Society of Certified Public Accountants, California CPA.

Holzmann, O.J., \& Robinson, T. (2006). Business combinations revisited. The Journal of Corporate Accounting \& Finance, $17(2), 75-78$.

Jhonson, R., \& Melicher, R. (1982). Financial management. Boston: Allyn and Bacon.

Keskinoğlu, S. (1961). Genel işletme ekonomisi dersleri. Eskişehir: Eskişehir İktisadi ve Ticari ilimler Akademisi Yayınları. Kıymetli Şen, İ., Üçoğlu, D., \& Terzi, S. (2015). Konsolide finansal raporlama. Bursa: Ekin Basın Yayın.

Mucuk, ì. (2003). Modern işletmecilik. İstanbul: Türkmen Kitabevi.

Müftüoğlu, T. (1989). Işletme iktisadı. Ankara: Turhan Kitabevi.

Özerhan, Y., \& Yanık, S. (2012). IFRS/IAS ile uyumlu açıklamalı ve örnek uygulamalı Türkiye Muhasebe Standartları/Türkiye Finansal Raporlama Standartları. Ankara: TÜRMOB Yayınları.

Pike, R., \& Neale, B. (1996). Corporate finance and investment. İngiltere: Prentice Hall.

Sarıkamış, C. (2003). Satın alma ve yeniden yapılandırma: Şirket birleşmeleri. İstanbul: Avcıol Basın Yayın.

Şahin, H. (1994). iktisada giriş. Bursa: Ezgi Kitabevi.

Tükenmez, M., Yükçü, S., Özkol, E., Özkan, S., \& Susmuş, T. (1999). Muhasebe sistemi uygulama tebliğine göre finansal yönetim. İzmir: Vizyon Yayınları.

Türk, H.S. (1986). Ticaret ortaklarının birleşmesinde nevilerin aynı olması koşulu. Ankara: Banka ve Ticaret Hukuku Araştırma Enstitüsü Yayınları, Yayın No: 186.

UFRS 3 İşletme Birleşmeleri.

Unay, C. (1997). Genel iktisat. Bursa: Ekin Yayınları.

Ülgen, H., \& Mirze, K. (2004). Işletmelerde stratejik yönetim. İstanbul: Literatür Yayıncılık.

Weston, F., \& Brigham, E. (1993). Essentials of managerial finance. Tenth Edition, USA: Harcourt Brace College Publishers.

Yıldırım, H. A., \& Kolotoğlu, O. (2003). Anonim ve limited şirketlerin kuruluşu, tasfiyesi, birleşmesi, devri, nevi değişikliği, bölünme ve hisse değişimi. Ankara: Yaklaşım Yayıncılık. 
This Page Intentionally Left Blank 